\title{
Controls on Barite Crystal Morphology during Abiotic Precipitation
}

\author{
Inoka H. Widanagamage ${ }^{1,2, *}$, Allison R. Waldron ${ }^{2}$ and Mihaela Glamoclija ${ }^{2}$ \\ 1 Department of Geology and Geological Engineering, University of Mississippi, P.O. Box 1848, \\ University, MS 38677-1848, USA \\ 2 Department of Earth and Environmental Sciences, Rutgers, The State University of New Jersey, \\ 101 Warren Street, New Brunswick, NJ 07102, USA; arw123@scarletmail.rutgers.edu (A.R.W.); \\ m.glamoclija@rutgers.edu (M.G.) \\ * Correspondence: ihwidana@olemiss.edu; Tel.: +1-662-915-2154; Fax: +1-662-915-5998
}

Received: 25 August 2018; Accepted: 19 October 2018; Published: 25 October 2018

\begin{abstract}
Barite $\left(\mathrm{BaSO}_{4}\right)$ is a stable and widely distributed mineral in Earth's crust. As such, barite has the potential to preserve specific geochemical and morphological characteristics representative of conditions at the time of its formation, which could be useful for interpretations of Earth's ancient rocks and paleoenvironments. In this study, we used variations in saturation index, solution temperature, solution chemistry, presence of organics, and $\mathrm{Mg}^{2+}$ and $\mathrm{Ca}^{2+}$ ions to investigate variations in barite crystal morphology. Through 42 experiments, we simulated poorly understood, low temperature spring settings similar to Zodletone Spring in Anadarko Basin, Oklahoma. Using SEM/EDS, we identified barite rosettes, rounded barite, euhedral/square-shaped barite, and elliptical barite as the crystal morphologies that directly reflect different formational settings. The X-ray diffraction (XRD) patterns revealed different crystallographic characters of the four distinct barite crystal morphologies; in particular, the samples that precipitated from supersaturated $\mathrm{SrSO}_{4}$ solution exhibited double peaks at $43^{\circ}$ 2-Theta, which matched barite with strontium substitution as barite might have incorporated strontium in its structure. Barite crystals that formed in the presence of organics in the initial solution exhibited a double peak at $33^{\circ}$ 2-Theta, which was absent in other samples. Confocal Raman microscopy indicated that all of the samples had typical barium sulfate bands, with a few differences in bands between the samples; for example, the $638 \mathrm{~cm}^{-1}$ band showed splitting or a double band between different samples. The samples that precipitated from solution with organics had organic compounds from the experimental solution included in their composition. In both cases, $\mathrm{C}-\mathrm{H}$ stretches from $2800 \mathrm{~cm}^{-1}$ to $3000 \mathrm{~cm}^{-1}$ were present as well as bands from $1350 \mathrm{~cm}^{-1}$ to $1500 \mathrm{~cm}^{-1}$, which are typical of organic compounds. Based on our experiments, the variation in barite crystal morphologies reflected changes in initial solution chemistry (or environmental settings).
\end{abstract}

Keywords: experimental; barite; crystallography; proxy; precipitation

\section{Introduction}

Barite $\left(\mathrm{BaSO}_{4}\right)$ has been an abundant and ubiquitous mineral in Earth's crust from the earliest history to the present day [1-5]. Due to its resistance to chemical weathering, it has remained intact in rocks since the Archean Eon. Early Earth's marine environments were anoxic and sulfate deposits prevailed, resulting in barite as the dominant or the only sulfate mineral within bedded sulfate deposits older than 2.4 Ga [2,5-10]. Diverse barite occurrences included what have been described as massive beds, laminations, rosettes, and nodules [2,5-7,9]. Barite could form through diagenetic replacement or hydrothermal exhalation, which were both common in the Archean environments [5]. As barite 
has been present throughout Earth's history, it has the potential to preserve specific geochemical and morphological characteristics that are representative of environmental conditions at the time of its formation. This could be useful for interpretations of ancient Earth's rocks and paleoenvironments and may perhaps aid estimates of biological presence during the evolution of early life.

In order to provide meaningful interpretations of geologically ancient environments that are associated with barite occurrences, we frequently use modern environments as analog systems. Within modern natural settings, barite will precipitate in any environment (e.g., marine, hydrothermal, continental) when barium-rich fluids mix with sulfate-rich anoxic solutions (e.g., brines) in the presence of sufficient concentrations of barium and sulfate ions [5,8-12]. Additionally, barite will precipitate in biologically maintained environments $[3,8,13]$. For example, sulfide-oxidizing bacteria are thought to play a major role in supplying sulfate to barium-rich waters in modern sulfur-rich continental springs [8].

Barite has been recognized as a useful paleoproductivity and paleoalkalinity proxy to understand past and present ocean productivity [14-16]. However, further studies of barite formation are needed to better understand the genesis of ancient barite deposits and potentially distinguish biologically maintained from purely abiotically precipitated barite $[2,5-7,9]$.

Numerous studies of modern marine environments have revealed that pelagic barite crystals mostly have uniform size and shape (submicron to $5 \mu \mathrm{m}$, subspherical, elliptical crystals), suggesting very stable nucleation and crystal growth environment. Ovoid and hexagonal barite crystals are interpreted as biotic forms of pelagic barite [10,17-20]. Hydrothermal marine barite has been extensively studied, and the dominant hydrothermal barite crystal morphologies are well-formed tabular, acicular/radiating tapered, and bladed to dendritic crystals [10,17,19-22]. For example, hydrothermal and cold seep barite will form cross-cutting tabular crystals that form rosette structures [23-25], while diagenetic barite typically consists of flat, tabular-shaped crystals [26] or nodules within sedimentary layers [27].

Modern continental warm springs are not extensively studied but show that barite crystal morphologies may vary from irregular dendritic, prism-like, and needle-like to rosette crystals [12,18]. Continental spring parameters change temporally and spatially (e.g., wet and dry season, degassing of deep-sourced fluids, turbulent mixing), creating diverse barite crystal morphologies. It has been identified that euhedral platy barite crystals precipitate at liquid-liquid interfaces and high ionic strength solutions, whereas stellate barite form at water-air interfaces in barite-supersaturated solutions [9]. Barite crystals grown directly from solution or nucleated on mineral surfaces (e.g., calcite) appear as euhedral, tabular, and rhombic crystals, while barite precipitated on microbial cells and within microbial EPS (Extracellular Polymeric Substances) exhibit subhedral and anhedral microcrystals [9]. As all of these studies were conducted in natural environments where conditions frequently mix (for example, biology is ubiquitous to all Earth settings, and it may be more or less expressed), it is challenging to precisely distinguish factors influencing specific crystal morphology unless the influence of each parameter is tested individually, which is best done within a well-controlled experimental setting.

Extensive experimental studies have been conducted to investigate the precipitation kinetics and mechanisms of mineral formation in hydrothermal settings $[19,20,28,29]$. It has been identified that solution chemistry, ion diffusion rate, and crystal growth rate play a major role in barite crystal morphology [19,20,28-31]. For example, limited crystal growth rate will result in the formation of dendritic/irregular crystals [28]. Furthermore, barite crystal morphology will depend on barite saturation state of the solution [28], $\mathrm{Ba}^{2+} / \mathrm{SO}_{4}{ }^{2-}$ ratio in the solution [29,32-34], mixing rate of the solution [29], temperature [28-30], and presence of organic compounds in the solution [35,36]. The chelating effect is dominant in the presence of organic compounds because cations tend to form organo-metallic complexes rather than reacting with anions in the solution. This will also change the ionic strength of the solution and affect the stability of the precipitated mineral phases [36]. Similarly, the solubility of mineral phases increases at the presence of organics [37]. The presence of humic 
substances may influence crystal growth and morphology [38,39]. Spontaneous barite precipitation from the solution can be hindered by the presence of organic compounds. This may result in crystal growth inhibition due to the adsorption of organic compounds to growing crystal surfaces [39]. Organic compounds could potentially shield the substrate on which other ions can form mineral phases [40,41].

In this study, we simulated continental spring settings and investigated variations in barite crystal morphology in response to changes in solution temperature and solution chemistry ( $\mathrm{Sr} / \mathrm{Ba}$ ratio, presence of $\mathrm{Mg}^{2+}$ or $\mathrm{Ca}^{2+}$ ions that are common $\mathrm{Ba}^{2+}$ substitutes in nature, and organic compounds). Our goal was to determine which of these parameters would result in different crystal morphology in order to better understand barite morphology from continental springs and aid in the interpretation of Earth's paleoenvironments.

\section{Methods}

\subsection{Experimental Design}

Barite precipitation experiments were performed under 42 different physical and chemical conditions, where one parameter (e.g., temperature, $\mathrm{Sr} / \mathrm{Ba}$ ratio) was changed at a time (see Table 1). Glassware and pipette tips were cleaned in $10 \% \mathrm{HNO}_{3}$ acid bath [30]. The $\mathrm{pH}$ of the experiments was maintained at a constant of about 6.5, and the initial saturation index (SI) was 3.55. The SI is determined as the difference between the log of the ion activity product (IAP) and the log of the solubility product $\left(\mathrm{Ksp}, \mathrm{Ksp}\right.$ barite $=\left[\mathrm{Ba}^{2+}\right]\left[\mathrm{SO}_{4}{ }^{2-}\right]$; barite $=9.82 \times 10^{-11} \mathrm{~mol}^{2} / \mathrm{L}^{2}$ at $\left.25^{\circ} \mathrm{C}\right)$, or log (IAP)-log (Ksp). We calculated the SI for our experimental barite minerals using visual Minteq software with Wateq4.dat database [42]. Potassium bisulfate $\left(\mathrm{KHSO}_{4}\right)$, Fisher Chemical Crystalline/Certified P1930 was dissolved in ultrapure Milli-Q water $(18.2 \mathrm{M} \Omega \mathrm{cm})$ to prepare a sulfate solution $(107 \mathrm{mM}$; $\mathrm{pH} 12)$ for use in our experiments. Barium chloride dihydrate $\left(\mathrm{BaCl}_{2} \cdot 2 \mathrm{H}_{2} \mathrm{O}\right.$, Mallinckrodt 3756$)$ and strontium nitrate anhydrous $\left(\mathrm{SrNO}_{3}\right.$, Fisher Chemical Crystalline/Certified ACS S549) solids were dissolved separately in ultrapure Milli-Q water to produce stock solutions ( $\mathrm{pH}$ 5.6). Various $\mathrm{Sr} / \mathrm{Ba}$ ratios in initial solutions for different barite precipitating experiments were prepared following the procedure described in Reference [30]. Diluted sulfate solution $\left(\mathrm{SO}_{4}{ }^{2-}\right)$ was added using a pipette to a solution with $\mathrm{Ba}^{2+}$ and $\mathrm{Sr}^{2+}$ (Table 1). Concentrations of $\mathrm{Sr}, \mathrm{Ba}$, and sulfate ions were assessed using Minteq in a way that the experiment would only precipitate barite within the solution. However, the experiments with $\mathrm{Sr} / \mathrm{Ba}$ ratio of 15 were supersaturated with respect to both barite and celestine (SI of 1.98) according to Minteq calculations. All of the experiments were completed instantly as barite had precipitated immediately upon the addition of the sulfate solution. The average time of the experiments was $3 \mathrm{~min}$. The duration of the precipitation was $10 \mathrm{~s}$ in total for each experiment. Barite precipitated instantaneously, and an instantaneous white "cloud" of microcrystalline barite was produced in all the experiments, as also described in Bonny and Jones [9]. After $10 \mathrm{~s}$, the solution was filtered using vacuum pump system. Filtering was completed within 3 min after which the residue was air-dried and stored in a Petri dish covered with the lid until SEM stubs were mounted. No evaporation occurred during the filtering process. The experiments were performed in duplicates, and four of the experiments were performed in triplicates as an experimental control. Cold experiments $\left(5{ }^{\circ} \mathrm{C}\right)$ were conducted in a refrigerator, and warm experiments $\left(40^{\circ} \mathrm{C}\right)$ were performed on top of a hot plate; the temperature of the experimental solution was controlled using a thermometer. In addition, $\mathrm{Sr}$ / Ba ratio of the initial solution was changed to 5 and 15 based on previous studies and previously published data considering natural environmental conditions in which barite precipitates in warm springs $[12,30]$. After precipitation, the solutions were filtered using $0.2 \mu \mathrm{m}$ nitrocellulose membranes and air-dried. Organic compounds (ethylenediaminetetraacetic acid (EDTA) or sodium formate $(\mathrm{HCOONa})$ ) were added to 16 experiments (Table 1) to test the influence of different types of organics on the crystal morphology. The additions of magnesium and calcium to the experimental solution can change the rate of barite precipitation and, therefore, the crystal morphology [43]. As 
ionic strength of the solution changes when calcium and magnesium ions are present in the system, it may affect the kinetics of the solutes and different barite morphologies can be formed $[29,36]$.

Table 1. The experimental conditions and the resulting crystal morphology for 42 barite precipitation experiments.

\begin{tabular}{|c|c|c|c|c|c|c|}
\hline Experiment & Temp $\left({ }^{\circ} \mathrm{C}\right)$ & $\mathrm{Sr} / \mathrm{Ba}$ & Organics & $\mathrm{MgCl}_{2}$ & $\mathrm{CaCl}_{2}$ & Dominant Crystal Morphology \\
\hline $4 \mathrm{a}$ & 5 & 5 & none & none & none & Rosettes \\
\hline $4 c$ & 5 & 5 & none & $0.5 \mathrm{M}$ & none & Rosettes \\
\hline $4 g$ & 5 & 5 & none & $1 \mathrm{M}$ & none & Rosettes \\
\hline $4 \mathrm{~d}$ & 5 & 5 & none & none & $0.5 \mathrm{M}$ & Rosettes \\
\hline $4 h$ & 5 & 5 & none & none & $1 \mathrm{M}$ & Rosettes \\
\hline $4 b$ & 5 & 5 & $0.01 \mathrm{M}$ EDTA & none & none & Rosettes \\
\hline $4 \mathrm{f}$ & 5 & 5 & $0.01 \mathrm{M}$ EDTA & $1 \mathrm{M}$ & $1 \mathrm{M}$ & Rosettes \\
\hline $4 \mathrm{i}$ & 5 & 5 & $1 \mathrm{M} \mathrm{HCOONa}$ & $1 \mathrm{M}$ & $1 \mathrm{M}$ & Elliptical crystals \\
\hline $6 a$ & 5 & 15 & none & none & none & Rounded crystals \\
\hline $6 \mathrm{~g}$ & 5 & 15 & none & $1 \mathrm{M}$ & none & Rounded crystals \\
\hline $6 \mathrm{~h}$ & 5 & 15 & none & none & $1 \mathrm{M}$ & Rounded crystals \\
\hline $6 f$ & 5 & 15 & 0.01M EDTA & $1 \mathrm{M}$ & $1 \mathrm{M}$ & Rounded crystals \\
\hline $6 \mathrm{i}$ & 5 & 15 & $1 \mathrm{M} \mathrm{HCOONa}$ & $1 \mathrm{M}$ & $1 \mathrm{M}$ & Elliptical crystals \\
\hline $1 \mathrm{a}$ & 20 & 5 & none & none & none & Rosettes \\
\hline $1 c$ & 20 & 5 & none & $0.5 \mathrm{M}$ & none & Rosettes \\
\hline $1 g$ & 20 & 5 & none & $1 \mathrm{M}$ & none & Rosettes \\
\hline $1 \mathrm{~d}$ & 20 & 5 & none & none & $0.5 \mathrm{M}$ & Rosettes \\
\hline $1 \mathrm{~h}$ & 20 & 5 & none & none & $1 \mathrm{M}$ & Rosettes \\
\hline $1 b$ & 20 & 5 & 0.01 M EDTA & none & none & Rosettes \\
\hline 1f & 20 & 5 & $0.01 \mathrm{M}$ EDTA & $1 \mathrm{M}$ & $1 \mathrm{M}$ & Rosettes \\
\hline $1 \mathrm{i}$ & 20 & 5 & 1M HCOONa & $1 \mathrm{M}$ & $1 \mathrm{M}$ & Elliptical crystals \\
\hline $3 a$ & 20 & 15 & none & none & none & Rounded crystals \\
\hline $3 c$ & 20 & 15 & none & $0.5 \mathrm{M}$ & none & Rounded crystals \\
\hline $3 g$ & 20 & 15 & none & $1 \mathrm{M}$ & none & Rounded crystals \\
\hline $3 d$ & 20 & 15 & none & none & $0.5 \mathrm{M}$ & Rounded crystals \\
\hline $3 h$ & 20 & 15 & none & none & $1 \mathrm{M}$ & Rounded crystals \\
\hline $3 b$ & 20 & 15 & 0.01 EDTA & none & none & Rounded crystals \\
\hline $3 f$ & 20 & 15 & 0.01 M EDTA & $1 \mathrm{M}$ & $1 \mathrm{M}$ & Rounded crystals \\
\hline $3 \mathrm{i}$ & 20 & 15 & $1 \mathrm{M} \mathrm{HCOONa}$ & $1 \mathrm{M}$ & $1 \mathrm{M}$ & Elliptical crystals \\
\hline $2 a$ & 40 & 5 & none & none & none & Rosettes and euhedral crystals \\
\hline $2 c$ & 40 & 5 & none & $0.5 \mathrm{M}$ & none & Rosettes \\
\hline $2 g$ & 40 & 5 & none & $1 \mathrm{M}$ & none & Rosettes and euhedral crystals \\
\hline $2 \mathrm{~d}$ & 40 & 5 & none & none & $0.5 \mathrm{M}$ & Rosettes \\
\hline $2 \mathrm{~h}$ & 40 & 5 & none & none & $1 \mathrm{M}$ & Rosettes and euhedral crystals \\
\hline $2 b$ & 40 & 5 & $0.01 \mathrm{M}$ EDTA & none & none & Rosettes and euhedral crystals \\
\hline $2 f$ & 40 & 5 & 0.01 M EDTA & $1 \mathrm{M}$ & $1 \mathrm{M}$ & Rosettes and euhedral crystals \\
\hline $2 \mathrm{i}$ & 40 & 5 & $1 \mathrm{M} \mathrm{HCOONa}$ & $1 \mathrm{M}$ & $1 \mathrm{M}$ & Elliptical crystals \\
\hline $5 a$ & 40 & 15 & none & none & none & Euhedral crystals \\
\hline $5 g$ & 40 & 15 & none & $1 \mathrm{M}$ & none & Euhedral crystals \\
\hline $5 \mathrm{~h}$ & 40 & 15 & none & none & $1 \mathrm{M}$ & Euhedral crystals \\
\hline $5 \mathrm{i}$ & 40 & 15 & 0.01 M EDTA & $1 \mathrm{M}$ & $1 \mathrm{M}$ & Euhedral crystals \\
\hline $5 f$ & 40 & 15 & $1 \mathrm{M} \mathrm{HCOONa}$ & $1 \mathrm{M}$ & $1 \mathrm{M}$ & Elliptical crystals \\
\hline
\end{tabular}

Note: $\mathrm{M}=\mathrm{mol} / \mathrm{L}$.

\subsection{Mineral Analyses}

Barite crystals were examined and analyzed using an ultra-high-resolution field emission scanning electron microscope (SEM) (Hitachi S-4800) (Hitachi High-Technologies Corporation, Tokyo, Japan) with an energy dispersive spectroscopy (EDS) detector. Dried samples were mounted on SEM stubs, coated with Ir (iridium) coating, and analyzed under standard vacuum conditions using $20 \mathrm{kV}$ (Hitachi High-Technologies Corporation, Tokyo, Japan). A Bruker AXS (Bruker Corporation, Karlsruhe, Germany), D8 Advance with Cu (1.5418 $\mathrm{A})$ radiation source was used to perform powder X-ray diffraction (XRD) analysis and EVA software was used to identify and analyze the mineral phases. Analytical conditions used for the run were $40 \mathrm{kV}, 25 \mathrm{~mA}, 0.5 \mathrm{~s}$ for each step and 3526 steps to complete the run, within $10^{\circ}$ to $80^{\circ}$ 2-Theta range. A Confocal Witec Alpha300R Raman system with $532 \mathrm{~nm}$ wavelength was used to identify mineral phases of the experimental precipitates. Barite minerals were analyzed using the $100 \times$ objective at five different points under different single spectrum conditions 
(different integration times and laser power) to ensure that the collected spectra were not conditioned by excessive laser power or any other analytical condition. The laser intensity used for the scanning of the samples was $44 \mathrm{~mW}$. Additionally, sample $2 \mathrm{~b}$ that contained organics was scanned (mapped) along the depth profile to ensure that the presence of 1346, 1435, and 3000 bands were not associated only with the grain surface and hence a result of contamination. Furthermore, high-resolution Raman maps were collected for the five distinct samples as identified by the SEM analysis.

\section{Results and Discussion}

Four distinct barite crystal morphologies were formed from 42 precipitation experiments (Figure 1 and Table 1). Rosette-like barite crystals (1-5 $\mathrm{m}$ in size) had flower-like habit and were the dominant morphologies. The rosette crystals formed under temperatures of $5{ }^{\circ} \mathrm{C}, 20{ }^{\circ} \mathrm{C}$, and $40{ }^{\circ} \mathrm{C}$ at a Sr/Ba ratio of 5 in the absence of organics (Figure 1A,B, Table 1). Well-rounded, spherical barite crystals (5-10 $\mu \mathrm{m}$ in size) were characteristic for experiments with a $\mathrm{Sr} / \mathrm{Ba}$ ratio of 15 , regardless of the temperature $\left(5^{\circ} \mathrm{C}, 20^{\circ} \mathrm{C}, 40{ }^{\circ} \mathrm{C}\right.$ ) (Figure $1 \mathrm{C}$ and Table 1). Euhedral (square shape) barite crystals (5-10 $\mu \mathrm{m}$ in size) were observed in experiments performed at $40^{\circ} \mathrm{C}$ in mixtures with or without other crystal morphologies (Figure 1D, Table 1). Elliptical or disc-like barite crystals (1-5 $\mu \mathrm{m}$ in size) were observed in experiments that contained organic substance (HOOCNa); the crystals formed in any temperature or at any $\mathrm{Sr} / \mathrm{Ba}$ ratio in the initial solution (Figure $1 \mathrm{E}$ ). Addition of $\mathrm{Mg}^{2+}$ and $\mathrm{Ca}^{2+}$ ions did not influence, in any observable way, the size or crystal morphology of the barite formed in the experiments using these ions. Boon and Jones [31] explained that the SI is the dominant parameter to form dendritic crystals. Our results revealed that besides constant SI, rosette crystals formed if the $\mathrm{Sr} / \mathrm{Ba}$ ratio remained constant and the temperature variations were not directly relevant for rosette crystallization. It has been revealed that the barite crystal morphology depends on $\mathrm{Ba}^{2+} / \mathrm{SO}_{4}{ }^{2-}$ ratio of the experimental solution [29]. However, our results showed diverse barite crystal morphologies at the same $\mathrm{Ba}^{2+} / \mathrm{SO}_{4}{ }^{2-}$ ratios but different temperatures, $\mathrm{Sr} / \mathrm{Ba}$ ratio, and the presence of inorganic or organic species in the initial experimental solution.

The X-ray powder diffraction analyses were conducted on distinct mineral forms: spherical, rosette-type, elliptical or disc-like, and euhedral-square crystals (experiments 3a, 4a, 4i, and 5a). All XRD patterns were identified as barite minerals; however, there were variations in peaks among the patterns (Figure 2, Table 2). Particularly, euhedral-square crystals (sample 5a) showed a single broad peak at $44^{\circ}$ 2-Theta, the rosette (sample $4 \mathrm{a}$ ) and elliptical or disc-like crystals (sample $4 \mathrm{i}$ ) showed a double peak at the same location, and well-rounded, spherical crystals (sample 3a) showed a broad, partially developed double peak. The position of $43^{\circ}$ 2-Theta for euhedral-square crystals (sample 5a) perfectly matched the EVA database pattern 00-039-1469 for synthetic barite with strontium substitution (Ba 0.75, Sr 0.25). When compared to barite and celestine standards D spacings for $44^{\circ} 2$-Theta peaks matched celestine minerals. This might have occurred due to the fact that the analyzed euhedral-square and well-rounded crystals had $\mathrm{Sr} / \mathrm{Ba}$ ratios of 15 in the initial solution, and these were supersaturated with respect to $\mathrm{SrSO}_{4}$ according to Minteq calculations. Therefore, barite might have incorporated strontium in its structure. The XRD pattern of celestine is very similar to the pattern of the barite, and they can be identified together because celestine may precipitate locally within the barite crystal [44]. This presence of minor quantities of celestine within barite minerals may occur due to temperature variations during barite precipitation, which would influence the thermodynamic stability of the barite-celestine solid solution [45]. The rosette and elliptical crystals (samples $4 \mathrm{a}$ and $4 \mathrm{i}$, respectively) had a double peak at $43^{\circ}$ 2-Theta (Figure 2). The first peak corresponded to the barite peak position, and the second peak corresponded to the celestine position (Table 2). The initial solution from which the rosette and elliptical crystals precipitated contained $\mathrm{BaSO}_{4}$ and was undersaturated in $\mathrm{SrSO}_{4}$; therefore, within the XRD pattern, the double peak at $43^{\circ}$ 2-Theta likely matched the strontium substitution within the barite structure. The elliptical barite crystals (sample 4i; Figure 1E) exhibited a double peak at $33^{\circ}$ 2-Theta, which was not present in any other analyzed samples. The double peak might have been due to the crystal structure that resulted from the presence of organics in the initial solution, and 
it was identified as a barite peak, not representing a new mineral phase (see Table 2). Additionally, the various experimental conditions (e.g., the presence of organics or changes in $\mathrm{Sr} / \mathrm{Ba}$ ratio) could have influenced the solubility of barite and celestine and the thermodynamics in the system, so the effects of crystal solubility might have been reflected in the barite crystal morphology [46].
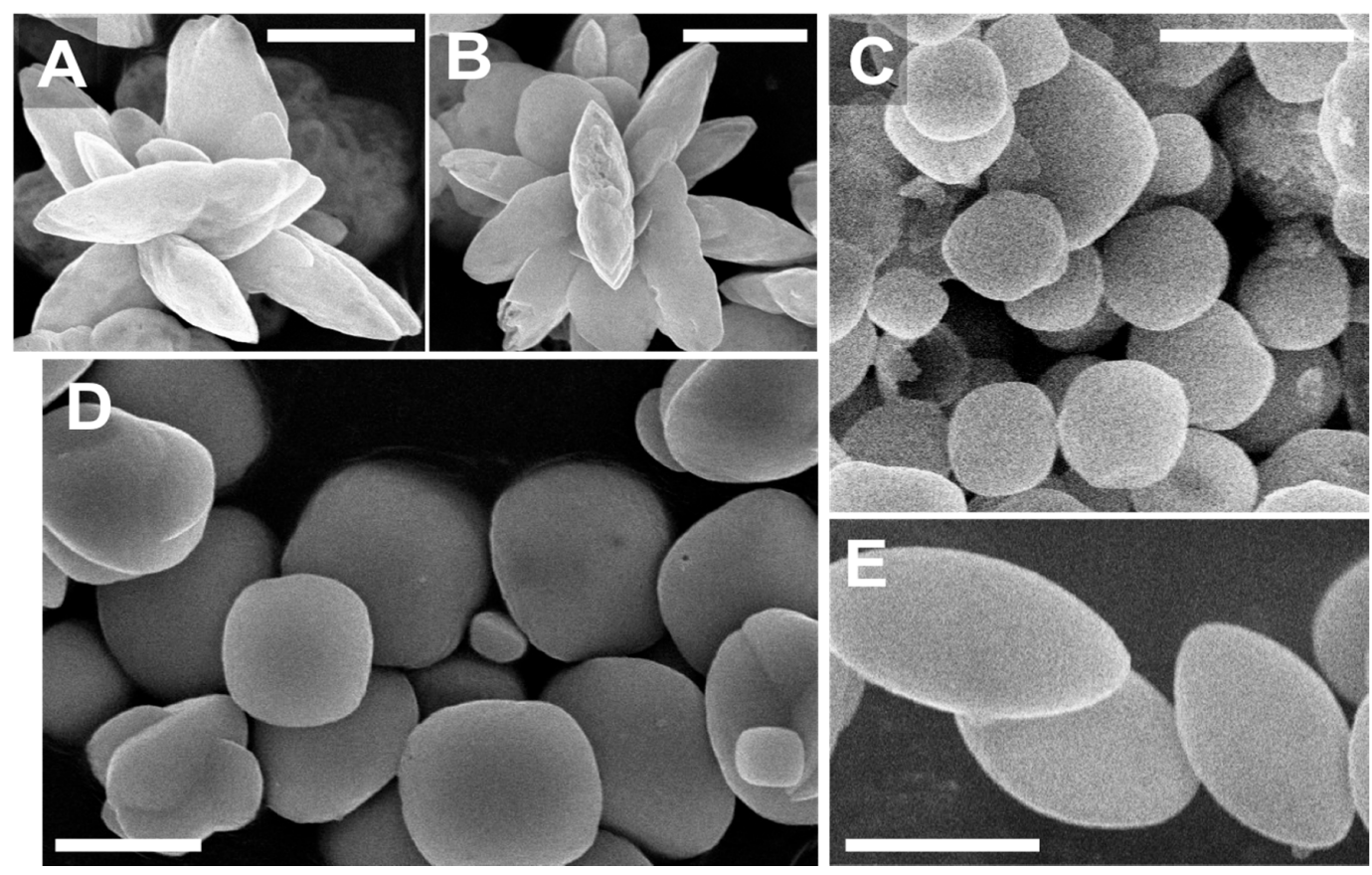

Figure 1. Scanning electron micrographs (SEM) of distinct crystal morphologies of synthetic barite. The scales on the images are $2 \mu \mathrm{m}$. (A,B) Rosette crystals resulting from experiment $4 \mathrm{a}$, performed at $5{ }^{\circ} \mathrm{C}$ with a Sr/Ba ratio of 5; (C) well-rounded crystals resulting from experiment 3a, performed at $20^{\circ} \mathrm{C}$ with a Sr/Ba ratio of 15 ; (D) euhedral crystals precipitated in experiment 5 a, performed at $40{ }^{\circ} \mathrm{C}$ with a Sr/Ba ratio of 15 ; (E) elliptical crystals precipitated in experiment $4 \mathrm{i}$, performed at $5{ }^{\circ} \mathrm{C}$ with a $\mathrm{Sr} / \mathrm{Ba}$ ratio of 5 with added organic compound sodium formate.

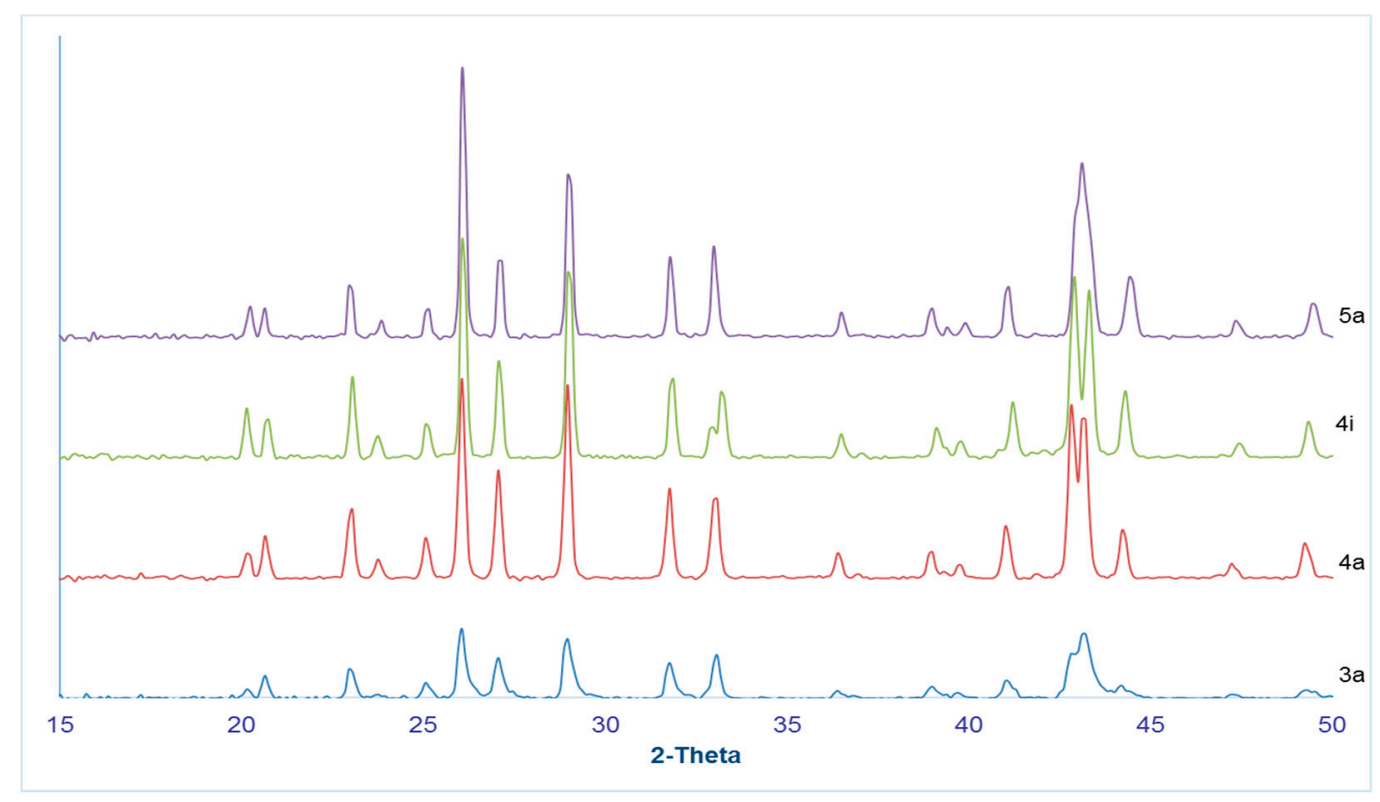

Figure 2. XRD patterns of the four distinct synthetic barite crystal morphologies: well-rounded crystals (sample 3a), rosette crystals (sample 4a), elliptical crystals (sample 4i), and euhedral crystals (sample 5a). 
Table 2. D-spacing calculated from XRD patterns of the four distinct synthetic barite crystal morphologies: well-rounded crystals (sample 3a), rosette crystals (sample 4a), elliptical crystals (sample 4i), and euhedral crystals (sample 5a). The barite and celestine standards were taken from Antao [47].

\begin{tabular}{|c|c|c|c|c|c|c|c|c|c|}
\hline $3 a$ & $4 a$ & $4 i$ & $5 a$ & Barite & Celestine & $3 a$ & $4 a$ & $4 i$ & $5 a$ \\
\hline 2-Theta & d & 2-Theta & d & 2-Theta & d & 2-Theta & d & d & d \\
\hline 23.3 & 3.71 & 23.3 & 3.71 & 23.3 & 3.71 & 23.3 & 3.71 & 4.4395 & 3.7655 \\
\hline 25.5 & 3.53 & 25.5 & 3.53 & 25.5 & 3.53 & 25.5 & 3.53 & 4.3373 & 3.4335 \\
\hline 26.05 & 3.4 & 26.05 & 3.4 & 26.05 & 3.4 & 26.05 & 3.4 & 3.8972 & 3.2915 \\
\hline 27.15 & 3.28 & 27.15 & 3.28 & 27.15 & 3.28 & 27.15 & 3.28 & 3.577 & 3.1758 \\
\hline 29.05 & 3.07 & 29.05 & 3.07 & 29.05 & 3.07 & 29.05 & 3.07 & 3.443 & 2.9682 \\
\hline 31.86 & 2.8 & 31.86 & 2.8 & 31.6 & 2.85 & 31.86 & 2.8 & 3.3179 & 2.7303 \\
\hline 32.96 & 2.71 & 32.96 & 2.71 & 31.86 & 2.8 & 32.96 & 2.71 & 3.1024 & 2.6729 \\
\hline 40.99 & 2.24 & 40.99 & 2.24 & 32.96 & 2.71 & 40.99 & 2.24 & 2.8346 & 2.3761 \\
\hline 42.89 & 2.13 & 42.89 & 2.13 & 40.99 & 2.24 & 42.89 & 2.13 & 2.727 & 2.2514 \\
\hline 43.49 & 2.03 & 43.49 & 2.03 & 42.89 & 2.13 & 40.99 & 2.27 & 2.4806 & 2.1394 \\
\hline 44 & 2.05 & 44 & 2.05 & 43.49 & 2.03 & 44.5 & 2.08 & 2.3236 & 2.045 \\
\hline \multirow[t]{11}{*}{44.5} & 2.08 & 44.5 & 2.08 & 44 & 2.05 & & & 2.21 & 2.0405 \\
\hline & & & & 44.5 & 2.08 & & & 2.1216 & 2.005 \\
\hline & & & & & & & & 2.12 & 1.9982 \\
\hline & & & & & & & & 2.1067 & 1.9454 \\
\hline & & & & & & & & 2.1038 & 1.7683 \\
\hline & & & & & & & & 2.056 & 1.6004 \\
\hline & & & & & & & & 1.8569 & 1.554 \\
\hline & & & & & & & & 1.7885 & 1.4748 \\
\hline & & & & & & & & 1.6737 & \\
\hline & & & & & & & & 1.5349 & \\
\hline & & & & & & & & 1.2625 & \\
\hline
\end{tabular}

Note: $\mathrm{d}$ = d-spacing values; Blue Words: barite peaks; Green Words: celestine peaks.

Confocal Raman mapping of crystals showed that all of the samples had typical barium sulfate bands [48], with a few differences in bands between the samples: The $638 \mathrm{~cm}^{-1}$ band showed splitting or was a double band; the well-rounded and euhedral-square crystals ( $3 \mathrm{a}$ and $5 \mathrm{a}$, respectively) exhibited a different ratio of this double peak or one band was weakly expressed, as seen in the spectrum of elliptical crystals (sample 4i; Figure 3). The difference in height between the 1073 and $1157 \mathrm{~cm}^{-1}$ band was obvious in all the analyzed samples. As spectral differences were not unique for any of the four samples, it was difficult to state the difference between well-rounded and euhedral-square crystals (5a and 3a samples), and more than one method was needed to further decipher any minor differences (Figure 3). Additionally, the Raman spectra characteristics of barite and celestine minerals were examined using the RRUFF database (rruff.info) barite minerals (ID R040036, X050028, X050028, R050342, R050335, and R050375), which all had double or triple peaks expressed in the $638 \mathrm{~cm}^{-1}$ band, identifying that these features were characteristic of barite minerals. Furthermore, the celestine minerals in the same database (ID R040007, R050008) exhibited almost identical Raman spectra. The peak region of 1000 and $1157 \mathrm{~cm}^{-1}$ had been ubiquitously present in all barite and celestine samples from RRUFF database as well. Therefore, based on the characteristics of the Raman data, it was not possible for us to identify whether or not any of the samples had incorporated any $\mathrm{Sr}$ in their structure. 


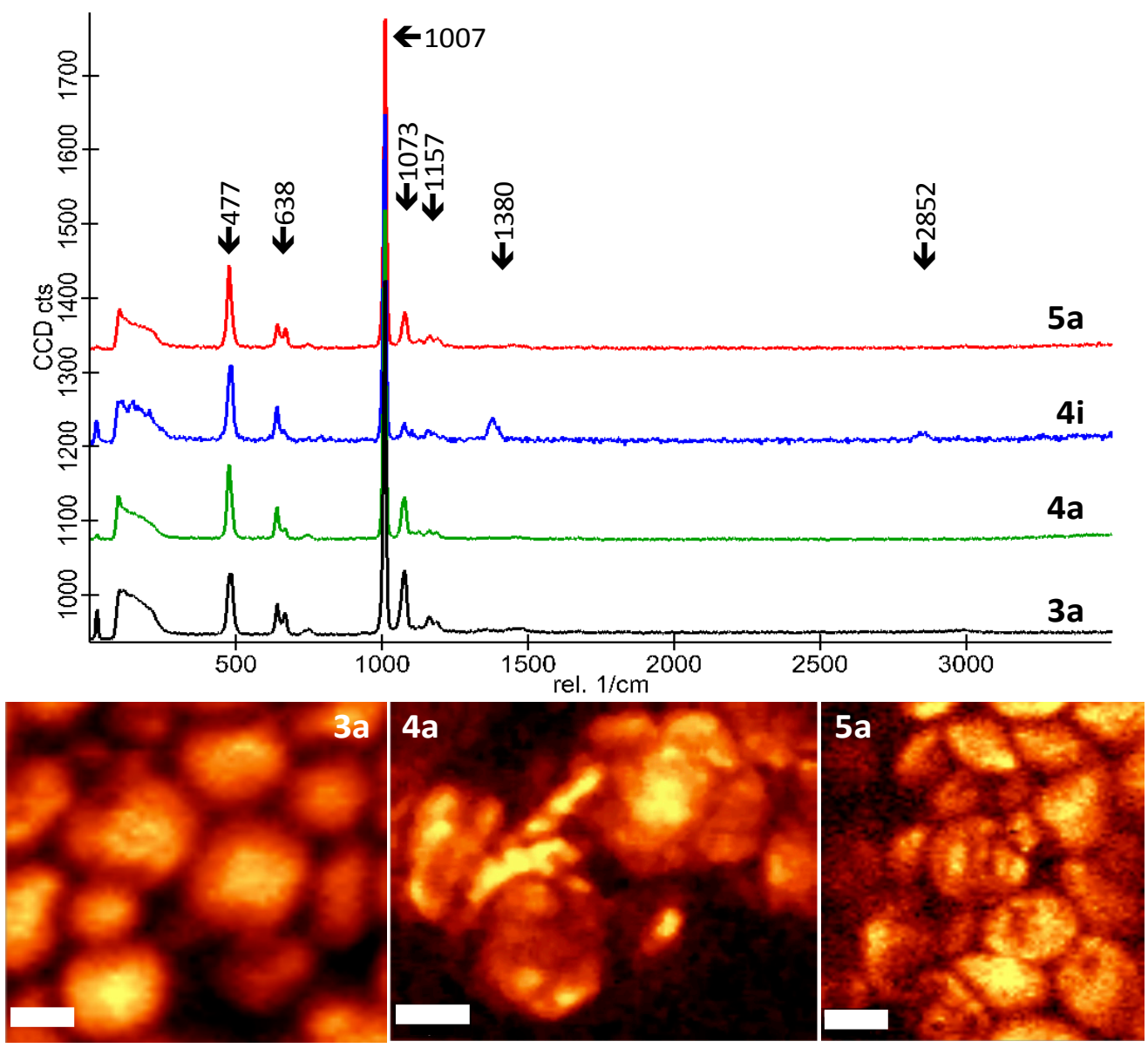

Figure 3. Raman spectra of the four distinct crystal morphologies: well-rounded crystals (sample 3a), rosette crystals (sample 4a), elliptical crystals (sample 4i), euhedral crystals (sample 5a). All of the spectra show typical Raman bands of barium sulfate with a strong band at $1007 \mathrm{~cm}^{-1}$ and medium to weak bands at $477,638,1073$, and $1157 \mathrm{~cm}^{-1}$. The differences in the spectra reflect changes in chemical composition due to addition of organics to the initial solution (sample 4i). Scale of all images is $5 \mu \mathrm{m}$.

The elliptical and rosette crystals (samples $4 \mathrm{i}$ and $2 \mathrm{~b}$; Figure 4) precipitated from solutions that contained organics (sodium formate and EDTA), and based on the Raman bands of these minerals, these grains seemed to have included organic compounds in their composition. In both cases, $\mathrm{C}-\mathrm{H}$ stretches from 2800 to $3000 \mathrm{~cm}^{-1}$ were present as well as bands from 1350 to $1500 \mathrm{~cm}^{-1}$; these are typical of organic compounds and represent disordered (D) and graphitic $(G)$ bands of graphitic carbon $[47,48]$. The mapping of the distribution of these bands in each of these samples was performed in order to investigate whether they were located within specific regions. We found that they corresponded closely with the distribution of $\mathrm{BaSO}_{4}$ peaks as no specific hot spots were found, which would have indicated deposition on the grain after the grain was formed. As we found such uniform distribution of organics and $\mathrm{BaSO}_{4}$, it would seem that these grains had incorporated organics into their structure. These results merit further investigations using different types of organic compounds to decipher whether specific crystallographic trends are related to specific compounds or organisms. 


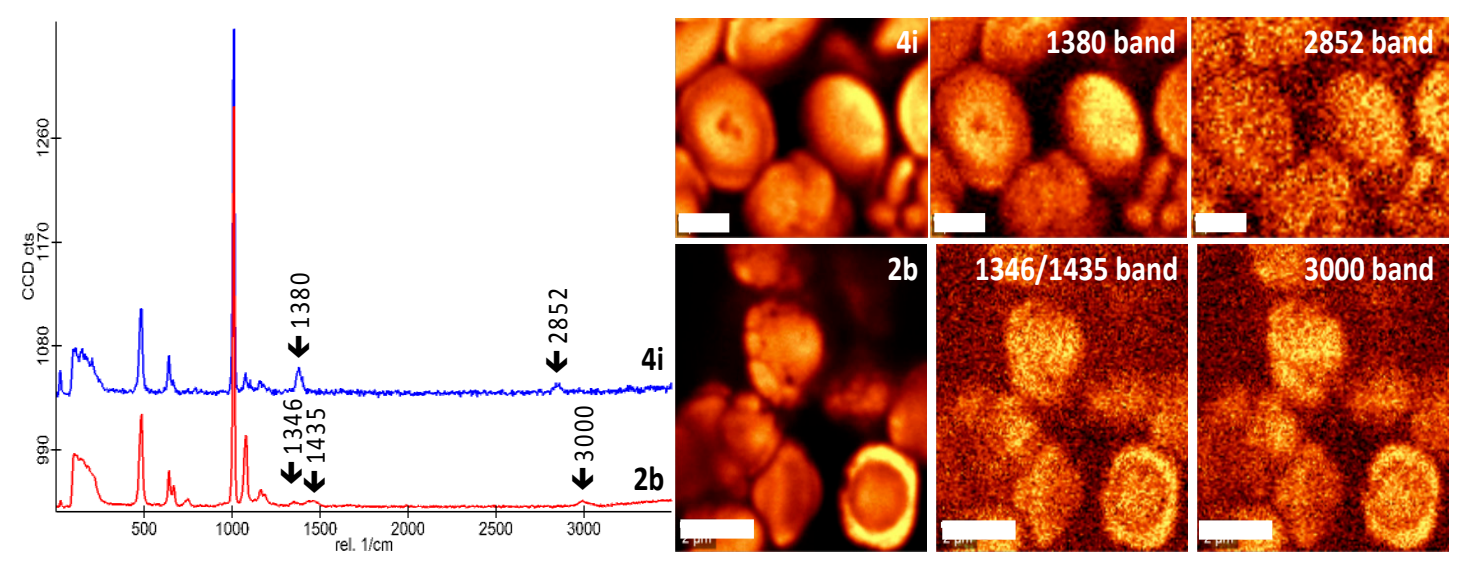

Figure 4. Raman spectra of samples $4 \mathrm{i}$ and $2 \mathrm{~b}$ precipitated in solutions with organic compounds. Scales on the $4 \mathrm{i}$ images are $1 \mu \mathrm{m}$, and scales on the $2 \mathrm{~b}$ images are $2 \mu \mathrm{m}$.

Variations in barite crystal morphologies are commonly controlled by the initial solution conditions from which the mineral is precipitated [28-30,33]. Rosette-like barite crystals like those that we identified in our experiments are commonly observed in warm springs [12,18]. The euhedral crystals were formed at higher temperatures $\left(40^{\circ} \mathrm{C}\right)$, which might have increased the diffusion rate of solutes and the kinetic energy of the molecules and thus changed precipitation conditions, resulting in the formation of a new crystal shape (Figure 1D). Previous studies have indicated that the growth rate of a crystal is the limiting factor for crystal precipitation; for example, when $\mathrm{Ba}^{2+}$ is in excess in solution relative to $\mathrm{SO}_{4}{ }^{2-}$, dendritic crystals will form due to an increase in growth rate when $\mathrm{Ba}^{2+} / \mathrm{SO}_{4}{ }^{2-}$ $>1$ under constant saturation [29]. Further, a decrease in growth rate would occur at extremely high ratios of $\mathrm{Ba}^{2+} / \mathrm{SO}_{4}{ }^{2-}>\sim 10$, indicating that there is a direct correlation between $\mathrm{Ba}^{2+} / \mathrm{SO}_{4}{ }^{2-}$ and the growth rate [29]. Unlike in Kowacz et al. [28], where precipitated crystals were 5-10 $\mu \mathrm{m}$ in size, our experiments produced crystals around $5 \mu \mathrm{m}$ in size under $\mathrm{Ba}^{2+} / \mathrm{SO}_{4}{ }^{2-}>10$ (Figure 1A,B). Whereas Kowacz et al. [28] explained crystal differences occurring specifically in room temperature precipitation experiments, our study showed that increased temperatures of $40^{\circ} \mathrm{C}$ formed larger crystals (Figure 1D), even when precipitated under $\mathrm{Ba}^{2+} / \mathrm{SO}_{4}{ }^{2-}>10$. It was focused on different $\mathrm{Ba}^{2+} / \mathrm{SO}_{4}{ }^{2-}$ ratios at a constant saturation index (either at 7.2 or 12.6) [29]. Our observations revealed that rather than the $\mathrm{Ba}^{2+} / \mathrm{SO}_{4}{ }^{2-}$ ratio, the $\mathrm{Sr} / \mathrm{Ba}$ ratios in the solution and, to a lesser extent, the temperature were the factors that most strongly influenced barite crystal morphology. Temperature plays an important role in chemical kinetics $[9,12,28]$. Mobility of ions and the rate of diffusion of ions correlated with the temperature of the solution. Experiment at $5{ }^{\circ} \mathrm{C}$ showed rosettes morphology; however, rounded barite crystals resulted in the experiments at $20^{\circ} \mathrm{C}$ and $40{ }^{\circ} \mathrm{C}$. This meant the temperature affected the barite crystal morphology. However, these morphology results were not only due to the change in temperature but also due to changes in solution chemistry.

Saturation index was the next important factor in barite precipitation according to our observations. Although a significant amount of barite precipitates in natural warm springs at very low saturation index values (e.g., 0-1.4), laboratory-based barite precipitation in our study and in previously performed precipitation experiments [30] have demonstrated that a minimum of 2.9 initial saturation index (or 7.2 [29]) is required for precipitation [30]. This indicates that the natural warm spring system is more complex than simulated conditions in a laboratory setting. Consequently, it is difficult to perfectly replicate natural warm springs in the laboratory. However, the only way to understand specific influence of the solution chemistry on the crystal formation is to systematically experiment within a controlled simplified experimental set up. In previously published experiments that mimicked hydrothermal settings, dendritic crystals were observed at $25^{\circ} \mathrm{C}$ and rectangular crystals were observed at $150{ }^{\circ} \mathrm{C}$ while the saturation index of the solution varied between 10 and 100 [28]. This was consistent with our study, where dendritic crystals precipitated at lower saturation index of 3.5 and at $25{ }^{\circ} \mathrm{C}$, indicating that, possibly, the temperature would condition the dendritic occurrence 
or the rapid precipitation of barite as suggested by Shikazono [28]. The rosettes of barite crystals have been observed from continental scale warm water spring site Zodletone, Oklahoma [12,28]. Our study showed that barite rosettes at controlled conditions were the dominant morphology under different experimental conditions. However, the rosettes that we observed in the experiments were less complex than natural barite rosettes, which exhibit very complex morphology. The presence of other ions affects the growth rate of different mineral faces [49]. The saturation index is an important parameter in crystal morphology, and dendritic crystals may result at SI of 3.0 of barite at excess sulfate in the system [31]. In our study, dendritic crystals and other morphologies were formed at the SI of barite at 3.5, indicating that dendritic particles may form at different saturation indexes and that temperature, presence of organics, and ion ratios are more important parameters in the formation of specific crystal morphology.

The spherical (round and euhedral) crystals, were precipitated under a Sr/Ba ratio of 15 and under different temperature ranges $\left(40^{\circ} \mathrm{C}, 20^{\circ} \mathrm{C}, 5^{\circ} \mathrm{C}\right)$. All initial solutions of the experiments were supersaturated with respect to $\mathrm{SrSO}_{4}$ (S.I. = 1.98), and this was also evident from our XRD data for the analyzed samples $3 \mathrm{a}$ and $5 \mathrm{a}$. More $\mathrm{Sr}$ ions in solution might have prompted the formation of spherical (well-rounded) crystals. Higher concentrations of Sr in solution (as seen in experiments 3a and 5a) could influence barite crystal morphology because Sr could get incorporated in barite crystal structure $[46,50]$. Similarly, spherical barite morphology has been identified in marine environments and attributed to the higher content of $\mathrm{Sr}^{2+}$ in seawater [10]. Godinho and Stack [49] explained that the presence of other ions (e.g., Sr) affect the crystal morphology. Their experiments showed that different incorporation rates of $\mathrm{Sr}$ within $(\mathrm{Sr}-\mathrm{Ba}) \mathrm{SO}_{4}$ solid solution changed the crystal morphology. In the presence on $\mathrm{SrCl}_{2}$ in the solution, smaller crystals homogeneous in size and morphology have been observed, which are less elongated along [010] direction [50]. It is possible that Sr inhibits crystal growth at specific sides of the crystal, which could result in various crystal morphologies. In our study, higher Sr/Ba ratio resulted in rounded barite crystals, which indicated the presence of nearly constant concentrations of ions around the nuclei. All sides of the crystals grew nearly at the same rate, which resulted in spherical crystal morphology. The experiments with $\mathrm{Sr} / \mathrm{Ba}$ ratio of 15 were supersaturated with respect to both barite and celestine, which caused the formation of spherical crystals.

The presence of organics in the initial solution (sodium formate) impacted crystal morphology (Table 1, Figures 3-5). Similar interpretations have been made in previous studies that included organics in the initial solution $[35,51,52]$. The organics will alter the crystal morphology by changing the nucleation and growth mechanisms [35,51,52] and, as seen in our Raman data, the organics (EDTA and sodium formate) may be included in the mineral composition. The addition of other chemical species might affect the ionic strength of the solution, which could change the rate of nucleation and rate of crystal growth [53]. The sites that attach the barium ions to sulfate ions could be clogged by other ions, and this might cause different crystal morphologies. Additionally, the hydronium ions could react with $\mathrm{Ba}^{2+}$ and $\mathrm{SO}_{4}{ }^{2-}$ in the presence of organic molecules, which could alter the growth of seed of barite crystals [53] and produce variations in the morphologies. Furthermore, the temperature changes would cause changes in the chemical kinetics of the solution because different chemical species have different kinetic energies within the solution [52]. Therefore, the diffusion rate ions could be different, which would affect the nucleation rate and cause changes in morphology [52].

Various barite crystal morphologies were observed during the precipitation from brine water [54]. The formation of needle-shape crystals can be related to a prolonged growth along [001] where [011] crystal face becomes the main surface. Barite crystals deform their rhombohedral habit when the saturation index is increased [54]. Alternatively, two-dimensional nucleation can form elongated morphology of barite crystals. High Sr concentrations may stabilize the [011] crystal face. In our experiments, added Sr at various concentrations (Table 1) and the resulting rounded barite crystals were formed at $\mathrm{Sr} / \mathrm{Ba}$ ratio of 15 . It is possible that the solution reached equilibrium with respect to $\mathrm{Sr}$, Ba ions, which resulted in the formation of rounded crystals. The inhibition effect is an important factor to consider when diverse barite crystal morphologies are present. Organic additives inhibit the 
precipitation of barite, which generates different morphologies [54]. Sr incorporates in barite crystal structure [50]. The presence of other ions (e.g., Sr) affects the crystal morphology due to different incorporation rates of $\mathrm{Sr}$ within $(\mathrm{Sr}-\mathrm{Ba}) \mathrm{SO}_{4}$ solid solution and change the crystal morphology [54]. In addition, it is possible that $\mathrm{Sr}$ inhibits crystal growth at specific sides of the crystal. This could explain the observation that we made in our experiments because Sr was added into each experimental solution. Furthermore, temperature plays an important role in chemical kinetics. The temperature will affect the diffusion of ions within the solution and therefore the barite crystal morphology. When temperature increases, the kinetic effects become important and it affects the morphology. One face of the barite crystal (e.g., 100) can be growing at a higher rate than the other (e.g., 110), which results in different crystal morphologies. Future experiments should be performed in order to understand the rate of growth at each crystal face at different temperatures. In addition to that, the presence of other ions (e.g., Mg or Ca) largely affects the barite crystal morphology [55]. These divalent ions could incorporate in barite crystal structure, which could change the rate of growth at different faces of the same crystal [55]. Step kinetics plays a significant role in determining the morphology of barite crystals. Barite crystallizes at orthorhombic crystal system; however, solution chemistry and the conditions could change barite crystal shape because ion incorporation $(\mathrm{Mg}, \mathrm{Ca}$, or $\mathrm{Sr})$ in barite growth steps could be crystallographic direction-specific [55].

When kinetic processes are limiting and the reaction has not reached equilibrium, the heterogeneity in the surrounding fluid can occur, which could lead to spatial heterogeneities within a solid solution, creating mineral zoning [56]. Our experiments were very short and it is likely no zoning occurred; however, expanding the precipitation time and the duration of the experiments would allow for inquiry of whether variations in Sr concentrations would cause the zoning effect in crystals. Compositional zonation explains the sequence of crystal growth, which could potentially explain the presence of other ions within the crystals (e.g., Sr in our experiments).
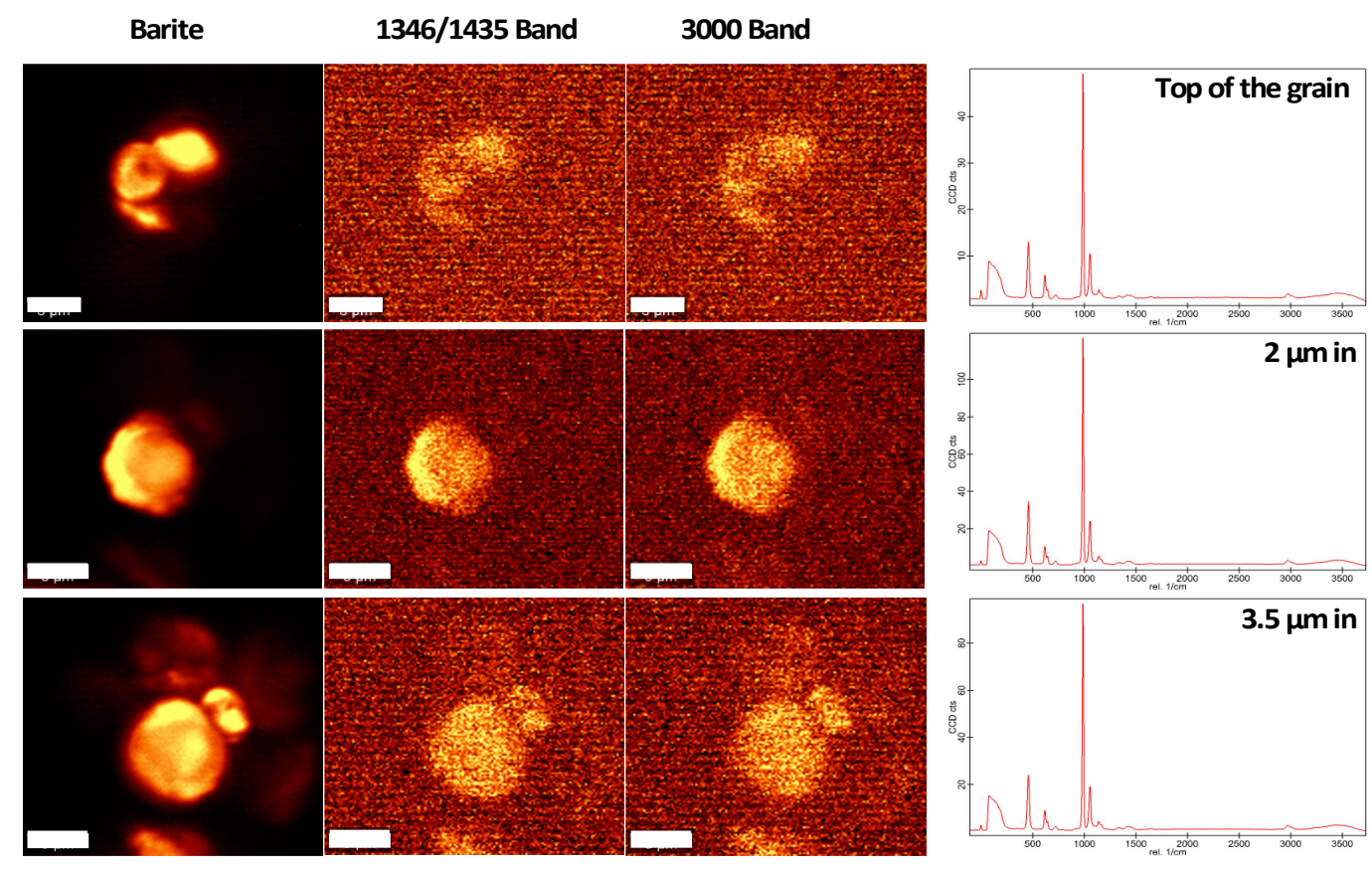

Figure 5. Depth Raman analyses of sample $2 b$ precipitated in solutions with organic compounds. Scales on all images are $3 \mu \mathrm{m}$. The first row shows maps produced on the top of the barite grain at 1346,1435 , and $3000 \mathrm{~cm}^{-1}$ bands. The second row shows maps produced for $2 \mu \mathrm{m}$ depth of the same grain and associated 1346, 1435, and $3000 \mathrm{~cm}^{-1}$ bands. The third row shows maps made at the $3.5 \mu \mathrm{m}$ depth of the same barite grain and its 1346,1435 , and $3000 \mathrm{~cm}^{-1}$ bands. On the right side are spectra at each of the depths, and they all contain 1346, 1435, and $3000 \mathrm{~cm}^{-1}$ bands that are characteristic of organics embedded in the grain. 


\section{Conclusions}

Our experiments were designed to simulate barite formation in continental spring environments and identify dominant controls on the crystal morphology in these kinds of settings. Our 42 experiments revealed that barite crystal morphology was largely affected by $\mathrm{Sr} / \mathrm{Ba}$ ratio in the solution, the solution temperature, and the presence of organics. Four distinct morphologies were identified in the experiments: (1) Rosette crystals were formed under temperatures of $5{ }^{\circ} \mathrm{C}, 20{ }^{\circ} \mathrm{C}$, and $40{ }^{\circ} \mathrm{C}$, with a Sr/Ba ratio of 5 (Figure 1A,B). (2) Well-rounded, spherical crystals were formed with a $\mathrm{Sr} / \mathrm{Ba}$ ratio of 15 , regardless of the temperature $\left(5^{\circ} \mathrm{C}, 20^{\circ} \mathrm{C}, 40^{\circ} \mathrm{C}\right)$ (Figure $\left.1 \mathrm{C}\right)$. (3) Euhedral (square) crystals were formed in all experiments performed at $40^{\circ} \mathrm{C}$ (Figure 1D). (4) Elliptical or disc-like crystals were formed in the presence of organic substances (sodium formate) at any temperature, regardless of the $\mathrm{Sr} / \mathrm{Ba}$ ratio in the initial solution (Figure $1 \mathrm{E}$ ).

Differences in crystallography were detected using XRD, which showed that crystals with higher $\mathrm{Sr} / \mathrm{Ba}$ ratios clearly resulted from substitution of $\mathrm{Sr}^{2+}$ for $\mathrm{Ba}^{2+}$, forming $\mathrm{SrSO}_{4}$. The experiments that included the additions of organic compounds resulted in precipitation of elliptical crystals when precipitated with sodium formate and no change in crystal shape when precipitated with EDTA; in both cases, Raman spectra revealed incorporation of organics into the crystal structure.

Author Contributions: Conceptualization, methodology, investigation, data curation, visualization, and writing—review and editing, I.H.W., M.G.; formal analysis, I.H.W., A.R.W.; writing—original draft preparation, I.H.W., M.G., A.R.W.; resources, supervision, project administration, funding acquisition, M.G.

Funding: This research was funded by NASA ASTEP grant NNX14AT28G to M.G.

Acknowledgments: We wish to thank two anonymous reviewers for their thorough reviews and discussions which significantly improved this work.

Conflicts of Interest: The authors declare no conflict of interest.

\section{References}

1. Burt, D.M.; Kirland, L.E.; Adams, P.M. Barite and Celestine detection in the thermal infrared-Possible application to determination of aqueous environments on Mars. In Proceedings of the 35th Lunar and Planetary Science Conference, League City, TX, USA, 15-19 March 2004.

2. Huston, D.L.; Logan, G.A. Barite, BIFs and bugs: Evidence for the evolution of the Earth's early hydrosphere. Earth Planet. Sci. Lett. 2004, 220, 41-55. [CrossRef]

3. Bonny, S.M.; Jones, B. Diatom mediated Barite precipitation in microbial mats calcifying at Stinking Springs, a warm Sulphur spring system in Northwestern Utah, U.S.A. Sediment. Geol. 2007, 194, 223-244. [CrossRef]

4. Chen, Y.X.; Zheng, Y.F.; Gao, X.Y.; Hu, Z. Multiphase solid inclusions in zoisite-bearing eclogite: Evidence for partial melting of ultrahigh-pressure metamorphic rocks during continental collision. Lithos 2014, 200, 1-21. [CrossRef]

5. Jewell, P.W. Bedded Barite in the geological record. From Global to Microbial. SPEM Special Publication, Society for Sedimentary Geology. Mar. Authogenesis 2000, 66, 147-161.

6. Bottrell, S.H.; Newton, R.J. Reconstruction of changes in global sulfur cycling from marine sulfate isotopes. Earth-Sci. Rev. 2006, 75, 59-83. [CrossRef]

7. Sanz-Montero, M.E.; Rodriguez-Aranda, J.P.; Garcia del Cura, M.A. Bio-induced precipitation of Barite and celestite in dolomite microbialites, Examples from Miocene lacustrine sequences in the Madrid and Duero Basins, Spain. Sediment. Geol. 2009, 222, 138-148. [CrossRef]

8. Senko, J.M.; Campbell, B.S.; Henriksen, J.R.; Elshahed, M.S.; Dewers, T.A.; Krumholz, L.R. Barite depositions resulting from phototrophic sulfide oxidizing bacterial activity. Geochim. Cosmochim. Acta 2004, 68, 773-780. [CrossRef]

9. Bonny, S.M.; Jones, B. Controls on the precipitation of Barite $\left(\mathrm{BaSO}_{4}\right)$ crystals in calcite travertine at Twitya Spring, a warm Sulphur spring in Canada's Northwest Territories. Sediment. Geol. 2008, 203, 36-53. [CrossRef]

10. Griffith, E.M.; Paytan, A. Barite in the ocean-occurrences. Geochemistry and paleoceanographic applications. Sedimentology 2012, 59, 1817-1835. [CrossRef] 
11. Younger, P. Barite Travertine from Southwestern Oklahoma and Western Central Colorado. Master's Thesis, Oklahoma State University, Norman, OK, USA, 1986.

12. Widanagamage, I.H.; Griffith, E.M.; Singer, D.M.; Scher, H.D.; Buckley, W.P.; Senko, J.M. Controls on stable Sr-isotope fractionation in continental Barite. Chem. Geol. 2015, 411, 215-227. [CrossRef]

13. Elshahed, M.S.; Senko, J.M.; Dewers, T.A.; Spear, J.R.; Najar, F.Z.; Kenton, S.M.; Roe, B.A.; Krumholz, L.R. Bacterial diversity and sulfur cycling in a mesophilic sulfide-rich spring. Appl. Environ. Microbiol. 2003, 69, 5609-5621. [CrossRef] [PubMed]

14. Dymond, J.; Suess, E.; Lyle, M. Barium in deep-sea sediment: A geochemical proxy for paleoproductivity. Paleoceanography 1992, 7, 163-181. [CrossRef]

15. Dymond, J.; Collier, R. Particulate barium fluxes and their relationships to biological productivity. Deep-Sea Res. Part II 1996, 43, 1283-1308. [CrossRef]

16. McManus, J.; Berelson, W.M.; Hammond, D.E.; Klinkhammer, G.P. Barium Cycling in the North Pacific: Implications for the Utility of Ba as a Paleoproductivity and Paleoalkalinity Proxy. Paleoceanography 1999, 14, 53-61. [CrossRef]

17. Bertram, M.A.; Cowen, J.P. Morphological and compositional evidence for biotic precipitation of marine barite. J. Mar. Res. 1997, 55, 577-593. [CrossRef]

18. London, D. The Barite roses of Oklahoma. Mineral. Rec. 2008, 39, 277-292.

19. Ray, D.; Kota, D.; Das, P.; Surya Prakash, L.; Khedekar, V.D. Microtexture and distribution of minerals in hydrothermal Barite-silica chimney from the Franklin seamount, SW Pacific: Constraints on mode of formation. Acta Geol. Sin. 2014, 88, 213-225.

20. Jamieson, J.W.; Hannington, M.D.; Tivey, M.K.; Hansten, T.; Williamson, N.M.B. Precipitation and growth of barite within hydrothermal vent deposits from the Endeavour Segment, Juan de Fuca Ridge. Geochim. Cosmochim. Acta 2016, 173, 64-85. [CrossRef]

21. Hofmann, R.; Baumann, A. Sr isotopic composition of brines from West German thermal springs. Neues. Jahrb. Geol. Palaontol. Mo. 1986, 10, 591-598.

22. Han, H.F.; Zhu, X.; Wen, H.; Zhao, C.; Xiao, F. Submarine hydrothermal contribution for the extreme element accumulation during the early Cambrian, South China. Ore Geol. Rev. 2017, 86, 297-308. [CrossRef]

23. Haymon, R.M.; Kastner, M. Hot-spring deposits on the East Pacific Rise at $21^{\circ} \mathrm{N}$-Preliminary description of mineralogy and genesis. Earth Planet. Sci. Lett. 1981, 53, 363-381. [CrossRef]

24. Fu, B.S.; Aharon, P.; Byerly, G.R.; Roberts, H.H. Barite chimneys on the Gulf-of- Mexico Slope-Initial report on their Petrography and Geochemistry. Geo-Mar. Lett. 1994, 14, 81-87. [CrossRef]

25. Paytan, A.; Mearon, S.; Cobb, K.; Kastner, M. Origin of marine barite deposits: Sr and S isotope characterization. Geology 2002, 30, 747-750. [CrossRef]

26. Dean, W.E.; Schreiber, B.C. Authigenic barite. In Proceedings of the Deep-Sea Drilling Project, Initial Reports; Gardner, J., Herring, J., Eds.; Government Printing Office: Washington, DC, USA, 1977; Volume 41, pp. 915-931.

27. Breheret, J.-G.; Brumsack, H.J. Barite concretions as evidence of pauses in sedimentation in the Marnes Bleues Formation of Vocontian Basin (SE France). Sediment. Geol. 2000, 130, 205-228. [CrossRef]

28. Shikazono, N. Precipitation of Barite in sulfate-sulfide deposits in back-arc basins. Geochim. Cosmochim. Acta 1994, 58, 2203-2213. [CrossRef]

29. Kowacz, M.; Putnis, C.V.; Putnis, A. The effect of cation:anion ratio in solution on the mechanism of Barite growth at constant supersaturation: Role of desolvation on the growth kinetics. Geochim. Cosmochim. Acta 2007, 71, 5168-5179. [CrossRef]

30. Widanagamage, I.H.; Schauble, E.A.; Scher, H.D.; Griffith, E.M. Stable strontium isotope fractionation in synthetic Barite. Geochim. Cosmochim. Acta 2014, 140, 58-75. [CrossRef]

31. Boon, M.; Jones, F. Barium sulfate crystallization from synthetic seawater. J. Cryst. Growth 2016, 16, 4646-4657. [CrossRef]

32. Wong, D.C.Y.; Jaworski, Z.; Nienow, A.W. Effect of ion excess on particle size and morphology during barium sulfate precipitation: An experimental study. Chem. Eng. Sci. 2001, 6, 727-734. [CrossRef] 
33. Judat, B.; Kind, M. Morphology and internal structure of barium sulfate-Derivation of a new growth mechanism. J. Colloid Interface Sci. 2004, 269, 341-353. [CrossRef] [PubMed]

34. Jones, F.; Olivera, A.; Parkinson, G.M.; Rohl, A.L.; Stanley, A.; Upson, T.J. The effect of calcium ions on the precipitation of barium sulphate 1: Calcium ions in the absence of organic additives. J. Cryst. Growth 2004, 262, 572-580. [CrossRef]

35. Jones, F.; Jones, P.; Ogden, M.I.; Richmond, W.R.; Rhol, A.L.; Saunders, M. The interaction of EDTA with barium sulfate. J. Colloid Interface Sci. 2007, 316, 553-561. [CrossRef] [PubMed]

36. Appleo, C.A.J.; Postma, D. Geochemistry, Groundwater and Pollution, 2nd ed.; CRC Press: Boca Raton, FL, USA, 2005; pp. 152-154.

37. Mavromatics, V.; Immenhauser, A.; Buhl, D.; Purgstaller, B.; Baldermann, A.; Dietzel, A. Effects of organic ligands or $\mathrm{Mg}$ partitioning and $\mathrm{Mg}$ isotope fractionation during low-temperature precipitation of calcite in the absence of growth rate effects. Geochim. Cosmochim. Acta 2017, 207, 139-153. [CrossRef]

38. Hennessy, A.J.B.; Graham, G.M. The effect of additives on the co-crystallization of calcium with barium sulphate. J. Cryst. Growth 2002, 237-239, 2153-2159. [CrossRef]

39. Smith, E.; Hamilton, J.; Davison, T.; Fullwood, N.J.; McGrath, M. The effect of humic substances on barite precipitation-dissolution behavior in natural and synthetic lake waters. Chem. Geol. 2004, 207, 81-89. [CrossRef]

40. Benton, J.; Collins, I.R.; Grimsey, I.; Parkinson, G.M.; Rodger, S. Nucleation, Growth and Inhibition of Barium Sulfate-controlled Modification with Organic and Inorganic Additives. Farady Discuss. 1993, 95, 281-297. [CrossRef]

41. Freeman, S.R.; Jones, F.; Ogden, A.O.; Richmand, W.R. Effect of benzoic acids on barite and calcite precipitation. Cryst. Growth Des. 2006, 6, 2579-2587. [CrossRef]

42. Gustafsson, J.P. Visual MINTEQ Version 2.52. Available online: http://www.lwr.kth.se/English/ OurSoftware/vminteq/ (accessed on 15 December 2016).

43. Bai, H.; Zhang, W.; Dengu, H.; Fu, Q.; Zhang, Q. Control of crystal morphology in Ploy (1-lactide) by adding nucleating agent. Macromolecules 2011, 44, 1233-1237. [CrossRef]

44. Singer, D.M.; Griffith, E.M.; Senko, J.M.; Fitzgibbon, K.; Widanagamage, I.H. Celestine in a sulfidic spring barite deposit-A potential biomarker? Chem. Geol. 2016, 440, 15-25. [CrossRef]

45. Glynn, P. Solid-solution solubilities and Thermodynamics: Sulfates, Carbonates and Halides. Rev. Mineral. Geochem. 2000. [CrossRef]

46. Antao, S.M. Structural trends for celestite $\left(\mathrm{SrSO}_{4}\right)$, anglesite $\left(\mathrm{PbSO}_{4}\right)$, and barite $\left(\mathrm{BasO}_{4}\right)$ : Confirmation of expected variations within the $\mathrm{SO}_{4}$ groups. Am. Mineral. 2012, 97, 661-665. [CrossRef]

47. Socrates, G. Infrared and Raman Characteristic Group Frequencies: Tables and Carts, 3rd ed.; Wiley and Sons Ltd.: Chester, UK, 2001; p. 347.

48. Fries, M.; Steel, A. Confocal Raman Microscopy, Springer Series in Optical Sciences; Dieing, T., Hollricher, O., Toporski, J., Eds.; Springer: New York, NY, USA, 2010; Volume 158, p. 111.

49. Godinho, J.R.; Stack, A.G. Growth Kinetics morphology of barite crystals derived from face-specific growth rates. Cryst. Growth Des. 2015, 15, 2064-2071. [CrossRef]

50. Averyt, K.B.; Paytan, A. Empirical coefficient for Sr and Ca in marine Barite: Implications for reconstructing seawater Sr and Ca concentrations. Geochem. Geophys. Geosyst. 2003, 4, 1-14. [CrossRef]

51. Cody, R.D.; Cody, A.M. Gypsum Nucleation and Crystal Morphology in Analog Saline Terrestrial Environments. J. Sediment. Petrol. 1988, 58, 247-255.

52. Cody, A.M.; Lee, H.; Cody, R.D.; Spry, P.G. The effects of chemical environmental on the nucleation, growth, and stability of ettringite $\left[\mathrm{Ca}_{3} \mathrm{Al}(\mathrm{OH})_{6}\right]_{2}\left(\mathrm{SO}_{4}\right)_{3} \cdot 2 \mathrm{H}_{2} \mathrm{O}$. Cem. Concr. Res. 2004, 34, 869-881. [CrossRef]

53. Ruiz-Agudo, C.; Putnis, C.V.; Ruiz-Agudo, E.; Putnis, A. The influence of $\mathrm{pH}$ on barite nucleation and growth. Chem. Geol. 2015, 391, 7-18. [CrossRef]

54. Mavredeki, E.; Neville, A.; Sorbie, K.S. Initial stages of barium sulfate formation at surfaces in the presence of inhibitors. Cryst. Growth Des. 2011, 11, 4751-4758. [CrossRef] 
55. Hong, M.; Xu, J.; Teng, H.H. Evolution of calcite growth morphology in the presence of magnesium: Implications for the dolomite problem. Geochim. Cosmochim. Acta 2016, 172, 55-64. [CrossRef]

56. Ling, F.T.; Hunter, H.A.; Fitts, J.P.; Peters, C.A.; Acerbo, A.S.; Huang, X.; Yan, Y.; Nazaretski, E.; Chu, Y. Nanospectroscopy Captures Nanoscale Compositional Zonation in Barite Solid Solutions. Sci. Rep. 2018, 8, 13041. [CrossRef] [PubMed]

(C) 2018 by the authors. Licensee MDPI, Basel, Switzerland. This article is an open access article distributed under the terms and conditions of the Creative Commons Attribution (CC BY) license (http:/ / creativecommons.org/licenses/by/4.0/). 